Transactions of the American Fisheries Society 129:811-826, 2000

(c) Copyright by the American Fisheries Society 2000

\title{
Gulf Sturgeon Spawning Migration and Habitat in the Choctawhatchee River System, Alabama-Florida
}

\author{
DewAyne A. Fox \\ North Carolina Cooperative Fish and Wildlife Research Unit, Department of Zoology, \\ North Carolina State University, Raleigh, North Carolina, 27695-7617, USA \\ Joseph E. HightoweR* \\ North Carolina Cooperative Fish and Wildlife Research Unit, U.S. Geological Survey, \\ Biological Resources Division, Department of Zoology, North Carolina State University, \\ Raleigh, North Carolina, 27695-7617, USA \\ Frank M. PARAuKa \\ U.S. Fish and Wildlife Service, Field Office, \\ 1612 June Avenue, Panama City, Florida 32405, USA
}

\begin{abstract}
Information about spawning migration and spawning habitat is essential to maintain and ultimately restore populations of endangered and threatened species of anadromous fish. We used ultrasonic and radiotelemetry to monitor the movements of 35 adult Gulf sturgeon Acipenser oxyrinchus desotoi (a subspecies of the Atlantic sturgeon A. oxyrinchus) as they moved between Choctawhatchee Bay and the Choctawhatchee River system during the spring of 1996 and 1997. Histological analysis of gonadal biopsies was used to determine the sex and reproductive status of individuals. Telemetry results and egg sampling were used to identify Gulf sturgeon spawning sites and to examine the roles that sex and reproductive status play in migratory behavior. Fertilized Gulf sturgeon eggs were collected in six locations in both the upper Choctawhatchee and Pea rivers. Hard bottom substrate, steep banks, and relatively high flows characterized collection sites. Ripe Gulf sturgeon occupied these spawning areas from late March through early May, which included the interval when Gulf sturgeon eggs were collected. For both sexes, ripe fish entered the Choctawhatchee River significantly earlier and at a lower water temperature and migrated further upstream than did nonripe fish. Males entered the Choctawhatchee River at a lower water temperature than females. Results from histology and telemetry support the hypothesis that male Gulf sturgeon may spawn annually, whereas females require more than 1 year between spawning events. Upper river hard bottom areas appear important for the successful spawning of Gulf sturgeon, and care should be taken to protect against habitat loss or degradation of known spawning habitat.
\end{abstract}

The Atlantic sturgeon Acipenser oxyrinchus comprises two disjunct subspecies along the Atlantic and Gulf coasts: the Gulf of Mexico form, A. o. desotoi (hereafter referred to as Gulf sturgeon) and the allopatric East Coast form, A. $O$. oxyrinchus (hereafter referred to as Atlantic sturgeon). Gulf sturgeon have one of the southernmost distributions of sturgeon worldwide (Bemis and Kynard 1997). Historically, Gulf sturgeon ranged throughout the Gulf of Mexico from Louisiana to Charlotte Harbor, Florida. However, populations have been severely reduced or extirpated throughout much of their range and present distribution is from east of the Mississippi River to the Suwannee River, Florida (U.S. Fish and Wildlife Service and

\footnotetext{
* Corresponding author: jhightower@ncsu.edu

Received December 22, 1998; accepted December 27, 1999
}

the Gulf States Marine Fisheries Commission 1995).

Historically, Gulf sturgeon supported substantial commercial and limited sport fisheries in Florida (U.S. Commission of Fish and Fisheries 1902; Burgess 1963; Smith and Clugston 1997). Overall, commercial fisheries showed many signs of overexploitation. Catches declined rapidly in most areas, and in 1984 the state of Florida ended harvest in all state waters. This was followed in 1991 by Federal designation of Gulf sturgeon as a threatened species. In an effort to prevent future declines and to bolster the current Gulf sturgeon population levels, the U. S. Fish and Wildlife Service and the Gulf States Marine Fisheries Commission completed a Recovery/Fishery Management Plan for the subspecies. The plan identified a need to collect information on Gulf sturgeon habitat requirements (U.S. Fish and Wildlife Service and the Gulf States 
Marine Fisheries Commission 1995). This plan specifically cites the need for information regarding the location, timing, and characteristics of essential spawning habitat. Recently, genetically distinct subunits of Gulf sturgeon were identified throughout the Gulf of Mexico (Stabile et al. 1996); therefore, efforts must be taken to examine spawning habitat and life history characteristics within individual river systems.

Early efforts to delineate Gulf sturgeon spawning locations were largely unsuccessful. Sampling for eggs and larvae of Gulf sturgeon in the Suwannee River with 1-m plankton nets stationed near the bottom produced neither, in spite of considerable sampling (Huff 1975). In the Apalachicola River, Florida, some incidental information on the location of spawning sites was derived by the capture of three Gulf sturgeon larvae (Wooley et al. 1982). Recent efforts to delineate Gulf sturgeon spawning habitat have relied primarily on artificial substrates to collect eggs (Marchant and Shutters 1996; Sulak and Clugston 1998). Over a 2-year period, collection of fertilized Gulf sturgeon eggs at four discrete locations in the Suwannee River provided the first information regarding the specific location and timing of spawning for this species (Marchant and Shutters 1996). These first insights provided a necessary starting point for more detailed studies. Recently, the collection of large numbers of eggs and detailed habitat characteristics of three Gulf sturgeon spawning locations has provided substantial new detail regarding habitat characteristics within the Suwannee River (Sulak and Clugston 1998; K. Sulak, U.S. Geological Survey-Biological Resources Division, personal communication).

A combination of approaches have been used to identify spawning sites for other sturgeon. Collections of eggs and larvae with artificial substrates, plankton nets, and beam trawls, combined with observations of spawning activity, have provided information regarding the spawning habitat requirements of white sturgeon A. transmontanus (McCabe 1990; Parsley et al. 1993; McCabe and Tracy 1994; Schaffter 1997). For shortnose sturgeon A. brevirostrum, movement to and from spawning sites has been characterized with telemetry; the reproductive status of fish at hypothesized spawning sites was determined by visual inspection, release of milt in males and movement patterns (Buckley and Kynard 1985; Hall et al. 1991; Kieffer and Kynard 1993). Lake sturgeon A. fulvescens spawning sites have been identified by direct observation of spawning behavior and by collection of fertilized eggs (Kempinger 1988; LaHaye et al. 1992). Sturgeon eggs in benthic fish intestines have been used to identify spawning sites for the Chinese sturgeon A. sinensis (ZhongLing and Yan 1991). Atlantic sturgeon spawning sites have been identified by use of telemetry, capture of larvae, collection of ripe individuals, and analysis of reproductive hormones and metabolites (Dovel and Berggren 1983; Van Eenennaam et al. 1996).

Our primary objective was to delineate probable spawning sites for Gulf sturgeon in the Choctawhatchee River system of Alabama and Florida. This objective was to be addressed by tracking radiotagged fish during the spawning season and by deploying egg collectors in areas where telemetry evidence indicated that adult fish were present. A secondary objective was to examine the role of sex and reproductive status on movement patterns and habitat selection.

\section{Study Area}

The Choctawhatchee River originates in southeastern Alabama and flows southward approximately $280 \mathrm{~km}$ through Florida, eventually emptying into Choctawhatchee Bay (Figure 1). The Choctawhatchee River drains a watershed in excess of $12,000 \mathrm{~km}^{2}$ and has an average discharge of $198 \mathrm{~m}^{3} / \mathrm{s}$, which makes it the third largest river in Florida (Bass et al. 1980). The watershed is mostly agricultural or forested and has relatively low levels of urbanization, especially in the headwaters. The Choctawhatchee River lacks a mainstem impoundment, which makes it unique compared with most other historical Gulf sturgeon rivers. Two major tributaries contribute to the Choctawhatchee River, the Pea River in the northern portion of the watershed and Holmes Creek, which is the major tributary in Florida. The Pea River is located almost entirely within Alabama, and there is a run-of-the-river dam on the Pea River at river kilometer (rkm) 191.

\section{Methods}

Netting operations using multiple multi-filament anchored gill nets (91.4-121.9 m long, 20-36 cm stretch mesh) were conducted within Choctawhatchee Bay during late winter and early spring of 1996 and 1997 (Figure 1). Nets were deployed perpendicular to the shoreline to maximize the intercept area for migrating fish and were checked at 4-h intervals to minimize mortality risk. Sampling was concluded when all transmitters had 


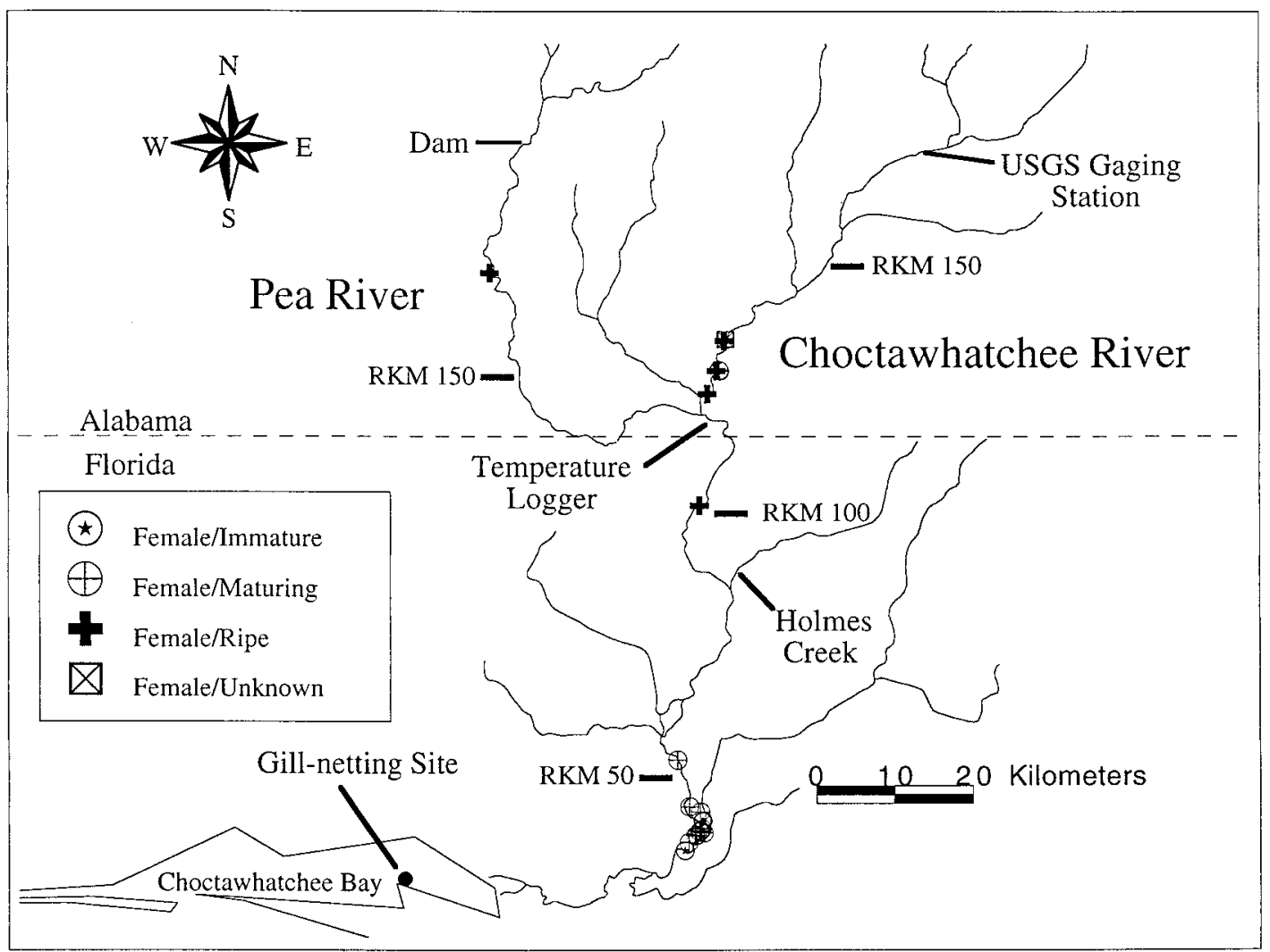

FIGURE 1.-Location of Choctawhatchee River system and plotted maximum upstream relocation (in river kilometers or rkm from the mouth of the river) and reproductive status for individual female Gulf sturgeon for the 1996 and 1997 field seasons. For fish captured in 1996 that returned in 1997, reproductive status in 1997 is unknown.

been implanted within fish large enough to be sexually mature (fork length $>1.3 \mathrm{~m}$; Huff 1975).

Captured fish were measured (both total length and fork length) to the nearest $1 \mathrm{~mm}$ and weighed to the nearest $0.5 \mathrm{~kg}$. Fish were placed into an anesthetic bath consisting of a $50-100 \mathrm{mg} / \mathrm{L} \mathrm{mix-}$ ture of tricaine methane sulfonate (tradename: MS222) and bay water (Harms and Bakal 1994). To determine the sex and reproductive status of individual fish (Huff 1975; Chapman et al. 1996), a 40-mm incision was made using a surgical scalpel on the mid ventral line about $40-60 \mathrm{~mm}$ anterior to the insertion of the pelvic fins. Upon reaching the peritoneum, a retractor was placed into the surgical area to spread the musculature and enable a clear view of the area. Gonadal tissue was located with use of a blunt probe. External appearance of the gonad was noted and then a biopsy $\left(1 \mathrm{~cm}^{3}\right.$ fragment) was taken using surgical forceps and a scalpel. Each sample was preserved in a vial con- taining buffered $10 \%$ formalin for histological analysis.

Thirty fish received internal radio transmitters (Advanced Telemetry Systems model 5A) that operated at $40 \mathrm{MHz}$, measured $2.0 \times 8.1 \mathrm{~cm}$ and weighed $40 \mathrm{~g}$ (in air). Transmitters were programmed with different duty cycles in the 2 years (12-h on-off in 1996 and 24-h in 1997), so all transmitters were guaranteed to last throughout the 1997 field season. To decrease signal attenuation, radio transmitter antennas $(35.6 \mathrm{~cm})$ exited the body cavity through a puncture of the lateral body wall, posterior to the primary incision site, made by a sterilized large-gauge (8/0) aspiration biopsy needle. During 1997, ultrasonic transmitters (Sonotronics model CHP-87-XL, $10.0 \times 3.5 \mathrm{~cm}$ and $110 \mathrm{~g}$ in air, expected battery life 30 months) were also implanted in all fish $(N=20)$ fitted with radio transmitters. The ultrasonic tags were used in a research project to examine Gulf sturgeon estua- 
rine and marine habitat use. In 1997, both radio and ultrasonic transmitters were coated with $\mathrm{Si}$ lastic (Dow Corning Products) to reduce the probability of tag extrusion.

The primary incision was closed using sterile resorbtive suture material. To ensure proper closure, a single interrupted suturing technique was applied. Surgical glue was placed over the incision sites to aid in wound closure and to help secure the tag in place until the wound began to heal. Following the application of surgical glue, a thin layer of petroleum jelly mixed with Betadine was placed over the incision areas to protect against infection.

Five externally mounted radio transmitters also were used to tag additional fish during this study. These transmitters (Advanced Telemetry Systems model $5 \mathrm{~A}, 40 \mathrm{mHz}$ ) were programmed with a duty cycle of 9 months on and 3 months off and had a guaranteed tag life exceeding 2 years. External transmitters were attached at the base of the dorsal fin (Carr et al. 1996) using a sterilized large-gauge $(8 / 0)$ aspiration biopsy needle. Teflon-coated attachment wires were fitted through the holes and affixed in place with a backing plate and crimps. Gonadal biopsies were collected as described above for all fish fitted with external transmitters.

To determine reproductive stage, gonadal tissue was stained with hematoxylin and eosin. Each sample was sectioned $(3 \mu)$, mounted on a glass slide, and then examined using light microscopy. Following Chapman et al. (1996), fish were classified as either immature, maturing, or ripe. According to this classification scheme, maturing fish had spawned in a previous year and were between spawning events at the time of collection.

Telemetry.-During 1996, searches within the Choctawhatchee River began $2 \mathrm{~d}$ following the release of the first radio-tagged fish. During 1997, searches in the Choctawhatchee River began in early February in an attempt to document dates of river entry for returning telemetered fish. Because fish captured in 1997 were implanted with both radio and ultrasonic transmitters, searches were conducted biweekly in Choctawhatchee Bay until all fish had left the bay and entered the Choctawhatchee River. All navigable portions of the Choctawhatchee River were searched at least once each week in 1996 and biweekly in 1997, until movement patterns indicated a probable end to the spawning season (i.e., ripe fish moving down to the lower portions of the river). In both years, following the end of the spawning season, we at- tempted to locate all tagged fish once biweekly until early July.

Habitat characterization.-Once the general location of a fish was determined, a more precise position was estimated based on changes in signal strength using a paper clip, which served as a weak antenna. At each fish location, we recorded latitude and longitude using a hand-held GPS unit. Temperature, dissolved oxygen, conductivity, and salinity were measured at both the surface and bottom using a YSI multi-meter. A substrate sample was obtained using a Petite PONAR sampler. Substrate samples were qualitatively categorized in the field as either silt, clay, sand, cobble, rock, or detritus. We also recorded water temperatures once every $2.4 \mathrm{~h}$ using a temperature logger at rkm 117 (Figure 1).

River flow rates were obtained from the U. S. Geological Survey gaging station (02361000) located at rkm 167 on the upper Choctawhatchee River near Newton, Alabama (Figure 1). Daily flow rates were used to examine the interaction between flow rates and movement patterns.

Egg collection.-Because the primary objective of this project was to identify Gulf sturgeon spawning sites, egg samplers were deployed in areas where telemetry evidence suggested that fish might be spawning (i.e., ripe fish maintaining position over or moving between hard bottom areas in the upper river). Egg samplers (modified from the design of Marchant and Shutters 1996) consisted of a red circular floor buffing pad $(55.9 \mathrm{~cm}$ or $68.6 \mathrm{~cm}$ in diameter) anchored to the bottom with welded rebar. Previous results regarding spawning locations of Gulf sturgeon (substrate type of rock-cobble and flow patterns of $>1 \mathrm{~m} / \mathrm{s}$ ) and other sturgeon species were considered when selecting sites for deploying egg samplers (Buckley and Kynard 1985; Marchant and Shutters 1996; Bemis et al. 1997; Wei et al. 1997; Sulak and Clugston 1998). Samplers were also positioned in areas where current patterns (i.e., eddies) possibly accumulated eggs (Sulak and Clugston 1998). Because Gulf sturgeon eggs probably adhere to the substrate almost immediately after spawning ( $\mathrm{Su}-$ lak and Clugston 1998), it seems probable that eggs collected on the samplers were spawned in close proximity to the collection area.

Sampling for eggs began when telemetered ripe fish began approaching areas where spawning was thought to occur (i.e., upstream hard bottom areas). Between 70 and 100 samplers were deployed in both the Choctawhatchee and Pea rivers and examined every $24-72 \mathrm{~h}$ for the presence of Gulf 
sturgeon eggs. Hard-bottom areas in the Choctawhatchee and Pea rivers are discrete in their distribution and tend to be associated with bends or turns in the river. In most cases, hard-bottom areas could be located by the presence of limestone bluffs along the riverbank that were visible at low flows. Additional qualitative information about substrate hardness was determined through the use of a 5-m fiberglass pole, which was pressed against the substrate. Sampling with this method was more rapid but less informative than with the PONAR unit and was employed when searching for hardbottom areas to be used for deploying egg samplers. The number of sampling pads deployed at a given site ranged between about 15 and 50, depending on the availability of samplers, apparent size of potential spawning area, and number of fish located by telemetry in the immediate area. We measured depth, substrate type, surface turbidity, conductivity, temperature, and dissolved oxygen at each location a Gulf sturgeon egg was collected. Sampling for eggs continued throughout the spawning season until temperatures approached the upper limit for larval survival $\left(25^{\circ} \mathrm{C}\right.$; Chapman and Carr 1995) and when it had appeared that most telemetered fish had left potential spawning sites and moved downriver towards areas typically occupied during the summer.

Data analyses.-Two-way analyses of variance (ANOVA) were used to examine the influence of sex and reproductive status on the migratory behavior of Gulf sturgeon. The main factors in the model were the sex and reproductive status of each fish. Year was included as a blocking effect to account for interannual variability in the maximum upstream distance migrated and date of river entry. All interactions between factors were tested, and when interactions were deemed nonsignificant $(\alpha$ $=0.05)$, they were excluded and the model was refitted. Maximum upstream distance was defined as the maximum distance upstream from the river mouth that an individual fish was relocated during the course of sampling. Distances upriver were determined by using geographic information systems software (ArcView version 3.0a, Environmental Systems Research Institute, Inc.). Date of river entry was defined as the date an individual fish was first relocated upstream of the river mouth $(\mathrm{rkm} 0)$. Temperature at time of river entry was recorded as the bottom temperature $\left({ }^{\circ} \mathrm{C}\right)$ at the time of first relocation of a fish in the river. We attempted to correct for differences in the timing between river searches by rounding the date of entry to weekly intervals, which were then as- signed as the last day of each weekly interval. Individual fish were treated as sampling units in all analyses to avoid the problems associated with serial correlation and individual variation in behavior (Kenward 1992). Excluded from the analyses were 1997 relocations of fish tagged in 1996 because the reproductive state of these fish was unknown during 1997.

\section{Results}

\section{Sex Ratios and Reproductive Status}

Netting operations began February 21, 1996 in Choctawhatchee Bay. Gulf sturgeon were generally encountered along sand flats at depths of 2 $6 \mathrm{~m}$. Of 17 Gulf sturgeon collected in 1996, 15 individuals (6 males and 9 females) were fitted with radio transmitters. In 1997, 35 Gulf sturgeon were captured, and a subsample of 20 fish ( 7 males and 13 females), chosen on the basis of size, general condition upon capture, and a combination of sex and reproductive status, received transmitters. Three fish died as a result of capture during the two field seasons. One was a telemetered male tagged in 1996 and recaptured in 1997; its incision site had completely healed and very little scaring was apparent. Upon examination, we determined that the antenna had previously broken away from the main tag body and was lost. Because this fish was tracked throughout the 1996 field season, it seems probable that the antenna became detached while the fish was in the bay.

Based on gonadal biopsies of male Gulf sturgeon, we found similar numbers of ripe $(N=6)$ and immature $(N=7)$ fish. No males were collected that were classified as maturing during this study. One male captured in 1996 and recaptured in 1997 was in ripe condition during both years. Based on gonadal biopsies of females, 14 were between spawning events (maturing state), 5 were ripe, and 3 were classified as immature. One female classified as ripe during 1996 was classified as maturing when recaptured during 1997 . Because we did not collect any maturing males, we combined immature and maturing females into a nonripe category for comparison with results for immature males.

\section{Telemetry}

During the spring spawning season in 1996, 14 of 15 tagged fish were relocated in the Choctawhatchee River on at least one occasion. A total of 193 relocations of telemetered fish, a mean of 14 relocations per individual, were made during this period. The first tagged fish moved into the Choc- 
tawhatchee River $7 \mathrm{~d}$ after tag implantation and release in the bay. The fish that did not migrate upriver during spring was relocated in the Choctawhatchee River for the first time on September 4, or $188 \mathrm{~d}$ after release. Relocation of this fish established that postsurgery survival was $100 \%$ for the 1996 season.

The first relocations in the 1997 field season were on March 26, when four fish were found in the lower Choctawhatchee River. These fish were relocated 4-13 d after tag implantation and release. Subsequent tracking of the main-stem Choctawhatchee River on March 31 and April 7, 1997 determined that two male fish tagged in 1996 were already in the upstream (upriver of rkm 120) habitat. A total of 230 relocations of fish radio-tagged in either 1996 or 1997 were made during the 1997 field season, or an average of 9 relocations per individual. All fish radio-tagged in 1997 were found within the Choctawhatchee River. The location of the last two fish on June 26 established that, as in 1996 , we achieved a postsurgery survival rate of $100 \%$.

With the exception of one fish recaptured during gill-netting operations, none of the five fish fitted with external transmitters in 1996 were relocated during 1997. For the one fish that was recaptured, the backing plate on the external transmitter had cracked and the tag was not securely attached. This external transmitter was removed and replaced with internal radio and ultrasonic transmitters.

Six of 10 fish equipped with internal transmitters during the 1996 season were relocated during 1997. One fish tagged in 1996 died in our gill nets; the remaining five fish were tracked during the 1997 season. One of these five either expelled its tag or died because the location of the transmitter never changed. Because this fish was found at rkm 30 during mid-August 1996 and then near the Choctawhatchee River mouth (rkm 0) during September 1996, it seems likely the fish either expelled the tag or died on its return to the bay. The four remaining fish were relocated during regular searches during the 1997 field season.

\section{Migration Timing and Movement Patterns}

Ripe Gulf sturgeon entered the Choctawhatchee River significantly earlier than did nonripe fish (Figure 2; $P=0.004$ ). Ripe fish typically entered the river from March to mid-April, whereas nonripe fish entered the river over a much more protracted period (March-September). There were no significant differences in the timing of river entry due to sex $(P=0.413)$ or year $(P=0.173)$ and no significant interactions $(P>0.05)$.

Water temperatures at time of river entry differed significantly by reproductive stage (cooler for ripe versus nonripe fish; $P<0.001$ ), sex (cooler for males than for females; $P=0.006$ ), and year $(P=0.011$; Figure 2$)$. There was a significant interaction between reproductive stage and year $(P$ $=0.001)$ that was due to greater difference in temperature at river entry between ripe and nonripe fish in 1996 compared with 1997. Compared with 1997, 1996 generally had cooler temperatures early in the year and a much more rapid warming trend with the arrival of summer. Temperature at the time of river entry for individual fish ranged from $11.2^{\circ} \mathrm{C}$ to $24.9^{\circ} \mathrm{C}$ and averaged $19.3^{\circ} \mathrm{C}$ for the 1996 field season. In 1997 , temperature at time of river entry ranged from $18.3^{\circ} \mathrm{C}$ to $27.1^{\circ} \mathrm{C}$ and averaged $21.2^{\circ} \mathrm{C}$.

There was a highly significant difference in the maximum distance migrated upriver between ripe and nonripe fish (Figure 2; $P<0.001$ ). Most ripe females were located above the confluence of the Pea and Choctawhatchee rivers (rkm 117), whereas nonripe females primarily occupied the lower river (Figure 1). A similar pattern was apparent for ripe versus nonripe males (Figure 3). Ripe males and females moved downstream after the spawning season to areas occupied by nonripe fish (Figures 4, 5). One exception to this pattern was a ripe male fish that moved to the lower river after the spawning season, and then was alternately located in the lower river and Choctawhatchee Bay during a 2-week period in May and June 1997. The spatial segregation between ripe and nonripe fish was compromised somewhat by one nonripe male in each year, and two nonripe females in 1997 (Figures 4, 5). We did not detect a significant difference between sexes in the maximum distance migrated upstream $(P=0.065)$, although males did migrate further upstream than did females during both years (Figures 4,5). There was a significant interaction between reproductive status and year $(P=0.011)$, which was due to the greater difference between ripe and nonripe fish observed in 1996.

Although we did not quantify the relationships, no clear pattern was found between timing of river entrance and flow patterns. Flow regimes varied considerably between 1996 and 1997 (Figures 4, 5). During 1996, flows were characterized by several pulses of high water, from the middle of February though late April, that then tapered off with the approach of summer. Flows in 1997 were high 

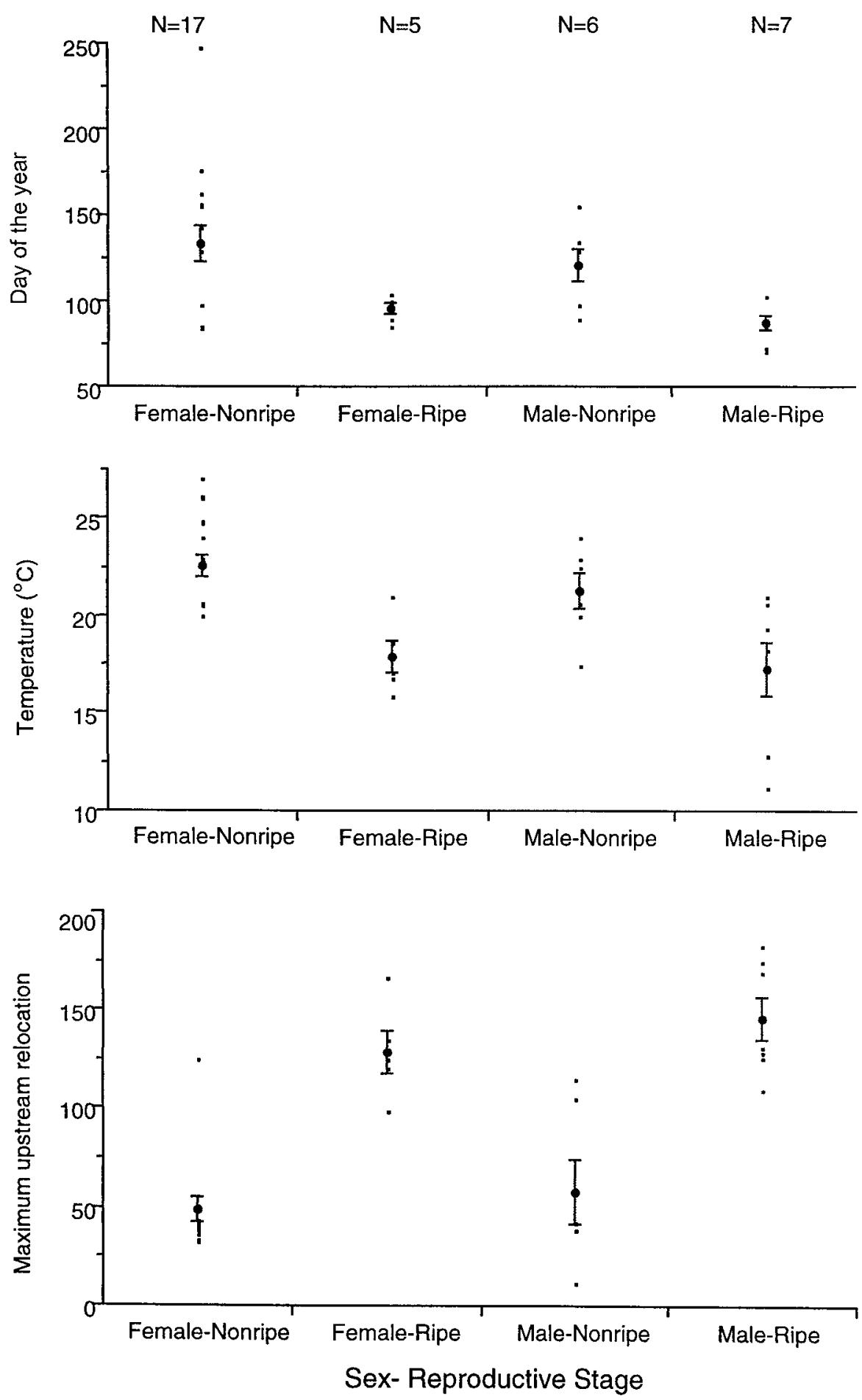

FIGURE 2.-Mean and SE for day of the year of river entry, water temperature at river entry $\left({ }^{\circ} \mathrm{C}\right)$, and maximum upstream relocation (in river kilometers or $\mathrm{rkm}$ ) for telemetered Gulf sturgeon in the Choctawhatchee River during 1996-1997. 


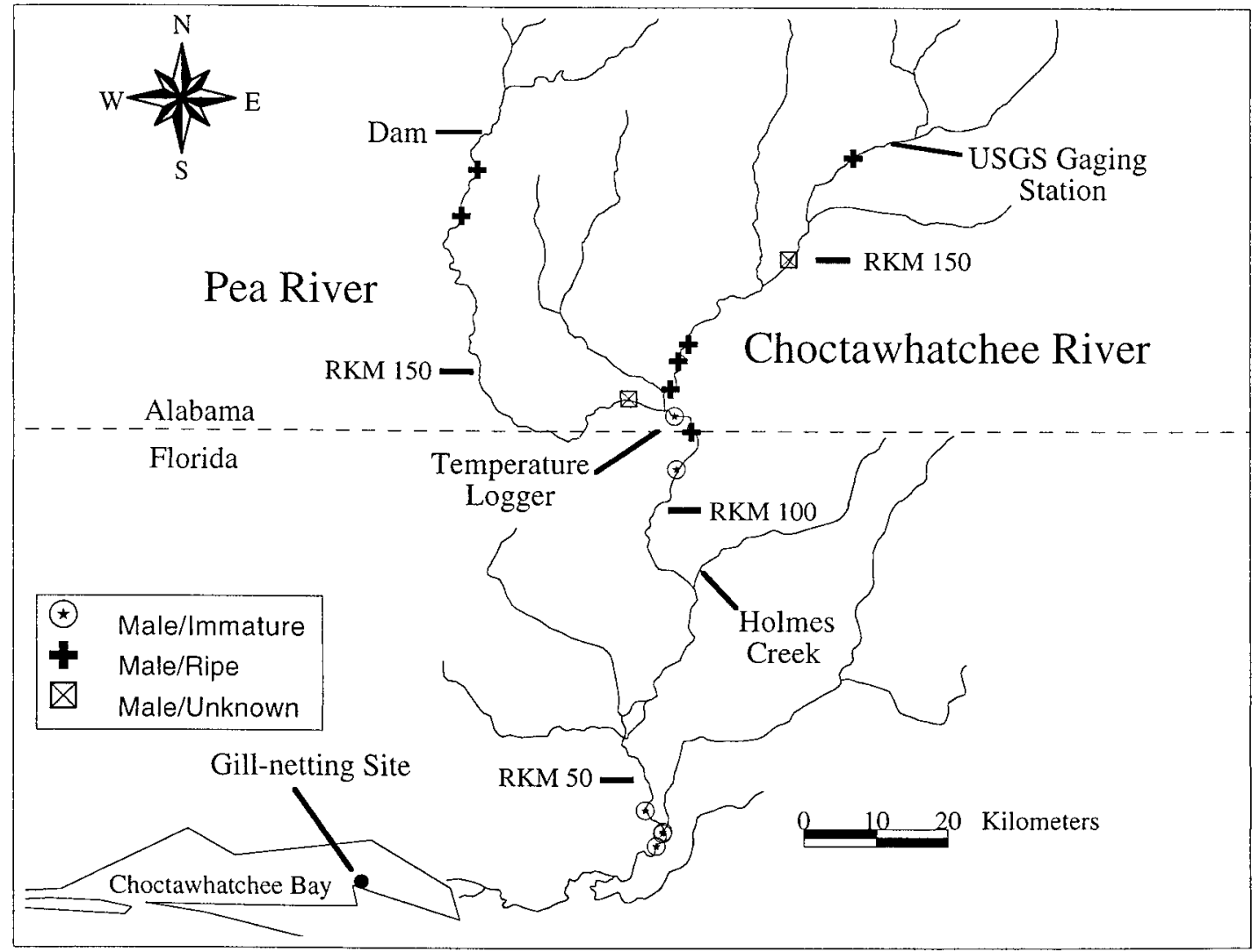

FIGURE 3.-Plotted maximum upstream relocation (in river kilometers, rkm, from the mouth of the river) and reproductive status for individual male Gulf sturgeon in the Choctawhatchee River system, 1996 and 1997 field seasons. For fish captured in 1996 that returned in 1997, reproductive status in 1997 is unknown.

in late February and early March and generally low during early summer, except for brief intervals of high flow.

\section{Egg Collection}

During 1996, telemetered fish moved over large areas and failed to remain at specific sites for more than a day or so on the upper Choctawhatchee and Pea rivers. Egg samplers were deployed from April 25 to May 16, but no Gulf sturgeon eggs were collected during the 1996 field season (Figure 6). In 1997 several telemetered Gulf sturgeon remained for 2-3 days in discrete areas in the upper portion of the Choctawhatchee River. A steep limestone bank and hard bottom substrate characterized each of these areas. Egg samplers were deployed continuously from April 4 through May 13 in these areas. Except for a few periods of very high flow in late April and early May (when we were unable to examine samplers), samplers were checked at 2-3 d intervals. During 1997, 42 fertilized Gulf sturgeon eggs were collected from six discrete (i.e., $>1 \mathrm{~km}$ apart) sites in both the Choctawhatchee and Pea rivers (Figure 6). All egg collection sites were located in Alabama above rkm 110. Eggs were collected on six different dates between April 18 and May 1.

Based on microscopic examination, egg developmental stages ranged from the morula to the advanced gastrulation stage (Conte et al. 1988). Based upon temperatures at time of egg collection and information on hatching times for hatcheryreared Gulf sturgeon (Parauka et al. 1991), we estimate that all eggs were no more than $48 \mathrm{~h}$ old at the time of collection.

The sites where Gulf sturgeon eggs were collected had limestone or gravel substrates and water depths ranging from 1.4 to $7.9 \mathrm{~m}$. No difference in surface and bottom temperatures were observed, and water temperatures ranged from $18.4^{\circ} \mathrm{C}$ to $22.0^{\circ} \mathrm{C}$ on dates when eggs were collected. Conductivity values ranged from 32 to $70 \mu \mathrm{S}$ and av- 
eraged $46 \mu \mathrm{S}$. Flow varied substantially during the interval when eggs were collected (Figure 5). Turbidity values fluctuated greatly in response to the timing of rainfall; values ranged from 12.3 to 114.0 nephelometric turbidity units (NTU) and averaged 52.5 NTU.

\section{Discussion}

The collection of fertilized Gulf sturgeon eggs combined with telemetry results provides evidence that upper river areas are important for successful reproduction of Gulf sturgeon within the Choctawhatchee River basin. Fertilized eggs were collected on hard-bottom areas in the upper river that were frequented by telemetered ripe Gulf sturgeon during the spawning season. Although Gulf sturgeon may spawn in other locations in the upper Choctawhatchee River, the spatial segregation of fish based on reproductive status indicates that little or no spawning occurs in the lower portions of the river. Previous research on Gulf sturgeon (Marchant and Shutters 1996; Sulak and Clugston 1998) and other sturgeon species (Artyukhin et al. 1979; Kynard 1997; Schaffter 1997) has shown a common pattern of spawning in the upper portions of the river.

Steep bluffs and an increased prevalence of limestone substrate characterize the upper river areas where ripe Gulf sturgeon were relocated and fertilized eggs were collected, whereas the lower river sites are predominantly sand. This change in substrate type occurs abruptly at around rkm 100. Information on Gulf sturgeon spawning in the Suwannee River also indicates that particular areas of hard-bottom habitat are important for successful reproduction of Gulf sturgeon (Marchant and Sutters 1996; Sulak and Clugston 1998).

There are several reasons why spawning at upstream hard-bottom areas would be expected. Gulf sturgeon eggs are adhesive (Parauka et al. 1991), so eggs spawned in areas of soft-bottom substrate (mud and sand) could become encapsulated with a layer of material that could possibly suffocate the developing egg. Upstream sites would be expected to have higher water quality, i.e., lower temperatures and higher oxygen levels. Upstream sites probably provide lowered risk of predation. Other sturgeon researchers have noted that developing larvae occupy the interstitial spaces between rocks and cobble, which may provide protection from predation (Kempinger 1988; LaHaye et al. 1992). Also, Choctawhatchee River survey results indicate that predatory fish occur more frequently in the tributaries and lower portions of the Choc- tawhatchee River (Livingston et al. 1991). In addition, spawning in upstream areas may prevent the newly hatched larvae from coming into contact with saline water before they are ready to undergo the necessary osmotic changes required for this transition to the marine environment (Van Eenennaam et al. 1996; Altinok 1997).

Our results support Chapman and Carr's (1995) hypothesis that reproductively mature individuals time their migration and arrival at the spawning grounds so that river conditions will optimize the survival of eggs and larval sturgeon $\left(15-20^{\circ} \mathrm{C}\right)$. All but one fertilized Gulf sturgeon egg collected in this study were obtained at temperatures less than $20^{\circ} \mathrm{C}$, which corresponds closely to recent findings in the Suwannee River (Sulak and Clugston 1998).

We obtained fertilized Gulf sturgeon eggs on six dates between April 18 and May 1, 1997, although sampling was conducted both earlier and later in the season. Spawning in the Suwannee River is somewhat earlier (late March through early May), occurring shortly after the March and April new moons and after water temperatures reach $17^{\circ} \mathrm{C}$ (Sulak and Clugston 1998). We found little evidence for the coupling of spawning with lunar cycles within the Choctawhatchee River system. We obtained eggs on a semiregular basis from $11 \mathrm{~d}$ after the April new moon until just before the new moon on May 6. Our results must be qualified, however, by the nonsystematic method of sampler deployment and the limited number $(N=11)$ of ripe fish tracked to the spawning grounds. Samplers were deployed at a series of different sites because we were more interested in identifying additional spawning locations than in quantifying the periodicity of spawning at any one site.

We found that Gulf sturgeon migratory patterns varied with respect to reproductive status and to a lesser extent by sex of the individual. Ripe fish of both sexes entered the Choctawhatchee River earlier and moved significantly further upstream compared with nonripe fish. We did not detect a difference between sexes in the date of river entry, but water temperatures at river entry were cooler for male Gulf sturgeon. Male Gulf sturgeon also tended to remain at spawning sites for longer periods compared with females. An earlier migration of male fish has also been documented for several European and North American sturgeon species (Dovel and Berggren 1983; Holcik 1989; O'Herron et al. 1993). In addition, there is evidence that this pattern may be exhibited by Gulf sturgeon in the Suwannee River (Carr et al. 1996). 

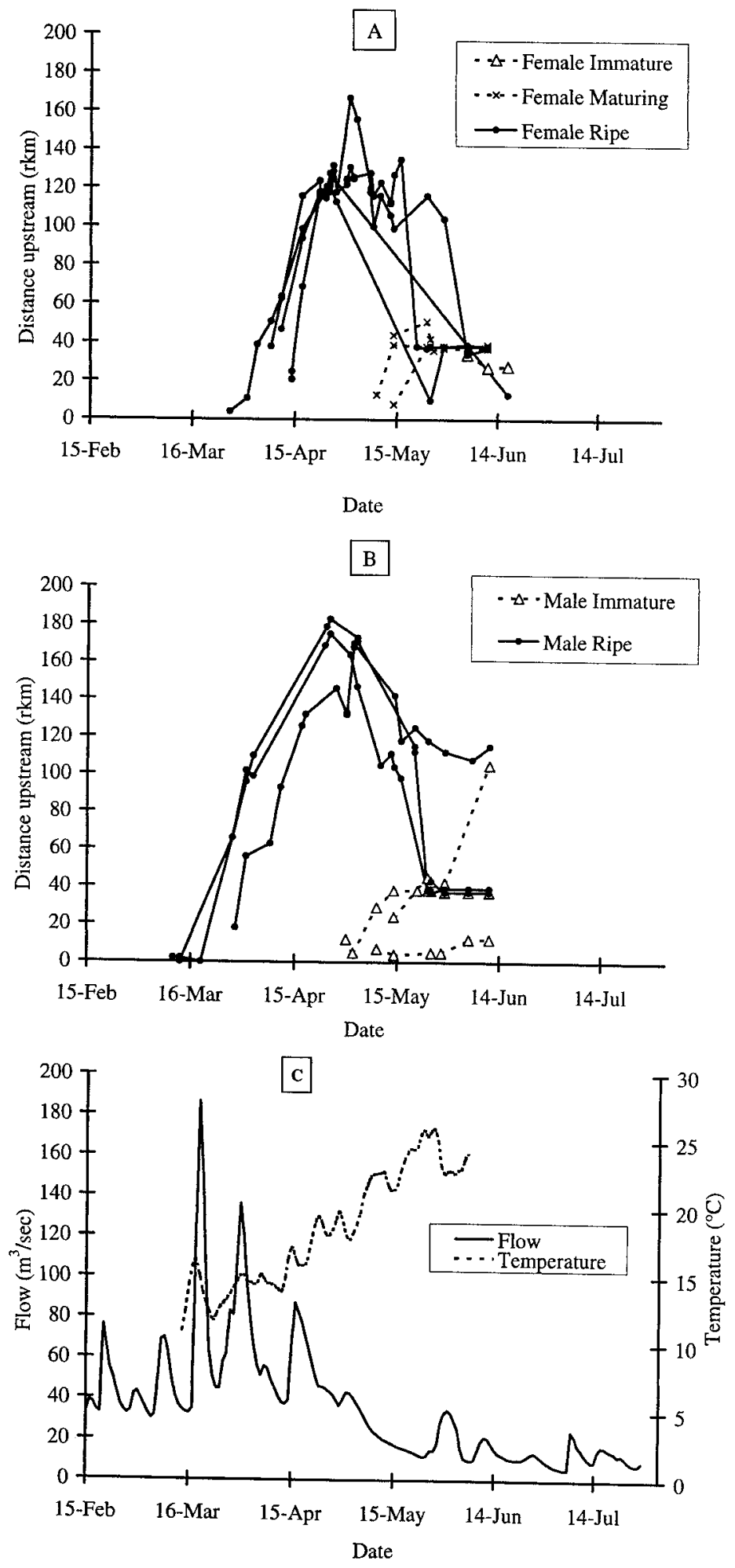
Gulf sturgeon began migrating from Choctawhatchee Bay into the Choctawhatchee River in late March and continued through the spring and into the summer months. The initiation of migration into the Choctawhatchee River was delayed compared with the Suwannee River; in the Suwannee, migration began in mid-February and concluded in early May (Carr et al. 1996; Foster and Clugston 1997). This difference in the start of migration is probably due to temperature differences because the Suwannee River typically warms earlier than the Choctawhatchee River (Frank Parauka, USFWS, personal communication). However, this cannot fully explain the more protracted timing of river entrance that we documented for immature and maturing individuals. A second explanation for the difference in the timing of migration of fish between river systems may be the location of capture sites. In previous studies on the Suwannee River, Gulf sturgeon were collected at the river mouth (Huff 1975; Carr et al. 1996; Foster and Clugston 1997), whereas we collected them in the bay prior to river entrance. The delayed start of migration that we observed for immature and maturing individuals is noteworthy when coupled with our observations that Gulf sturgeon appeared to be actively feeding within Choctawhatchee Bay. We hypothesize that mature, nonspawning Gulf sturgeon may be utilizing estuarine habitat to a greater degree than previously thought. Because foraging ceases while adult Gulf sturgeon are in the river (Clugston et al. 1995), extended periods of estuarine and marine residency may be important in rebuilding of energy reserves and gonadal recrudescence during nonspawning years.

Gulf sturgeon appeared to be foraging within Choctawhatchee Bay before initiating their upstream migrations. Upon capture, several fish either regurgitated or passed fecal material containing large numbers of decapod crustaceans, including blue crabs Callinectes sapidus and Lepedophthalmus $(=$ Callianassa) louisianensis (ghost shrimp family: Callianassidae). Necropsy results for a fish that died during capture in 1996 indicated that the fish had been feeding exclusively on both ghost shrimps and Leptalpheus forceps a commensal species in the family Alpheidae (Richard
Heard, Gulf Coast Research Laboratory, personnel communication). These prey items occur within Choctawhatchee Bay.

Our results, and those of Foster and Clugston (1997), support the hypothesis that Gulf sturgeon have adapted to erratic winter-spring flows and begin their migration when water temperatures approach some thermal minimum (about $18^{\circ} \mathrm{C}$ ). The average water temperatures when ripe fish began migrating into the Choctawhatchee River were comparable to those reported for the Suwannee River (Foster 1993; Chapman and Carr 1995). Similar to Foster and Clugston (1997), we did not detect evidence for a relationship between flows and the timing of river entrance. In contrast, Chapman and Carr (1995) reported that a strong positive correlation existed between high discharge levels and the initiation of migration for Gulf sturgeon in the Suwannee River.

Only 6 of 10 Gulf sturgeon receiving internal transmitters in 1996 were located in the Choctawhatchee River during 1997. This low return rate is somewhat problematic, given that Gulf sturgeon, unlike their Atlantic counterparts, are thought to return to rivers each year regardless of reproductive condition (Carr et al. 1996). The low return rate may be due to straying to other river systems, their remaining in the Gulf of Mexico or estuarine waters, transmitter failure, or expulsion of the transmitter. Transmitter failure cannot be ruled out, but it seems unlikely that such a large number of tags would fail prematurely. Straying to neighboring river systems may account to some extent for the low return rate. In July of 1998, Florida Department of Environmental Protection researchers relocated one of our 20 telemetered Gulf sturgeon in the Escambia River ( $>100 \mathrm{~km}$ from Choctawhatchee River). Despite this observation, a high rate of straying seems inconsistent with recent genetic evidence that Gulf sturgeon exhibit high fidelity to their natal rivers (Stabile et al. 1996). We hypothesize that some fish remain in marine or estuarine waters for a year or more where they undergo gonadal recrudescence. The late summer return of immature and maturing individuals provides evidence that a prolonged period of freshwater residency may not be required for all Gulf

$\leftarrow$

FIGURE 4.-Choctawhatchee River relocations (in river kilometers, rkm, upstream from the river mouth), by date, for (A) individual female and (B) male Gulf sturgeon tagged during the 1996 field season. Symbols indicate reproductive status. Panel (C) represents averaged daily flow rates $\left(\mathrm{m}^{3} / \mathrm{s}\right)$ and daily temperatures $\left({ }^{\circ} \mathrm{C}\right)$ in the Choctawhatchee River by date. 

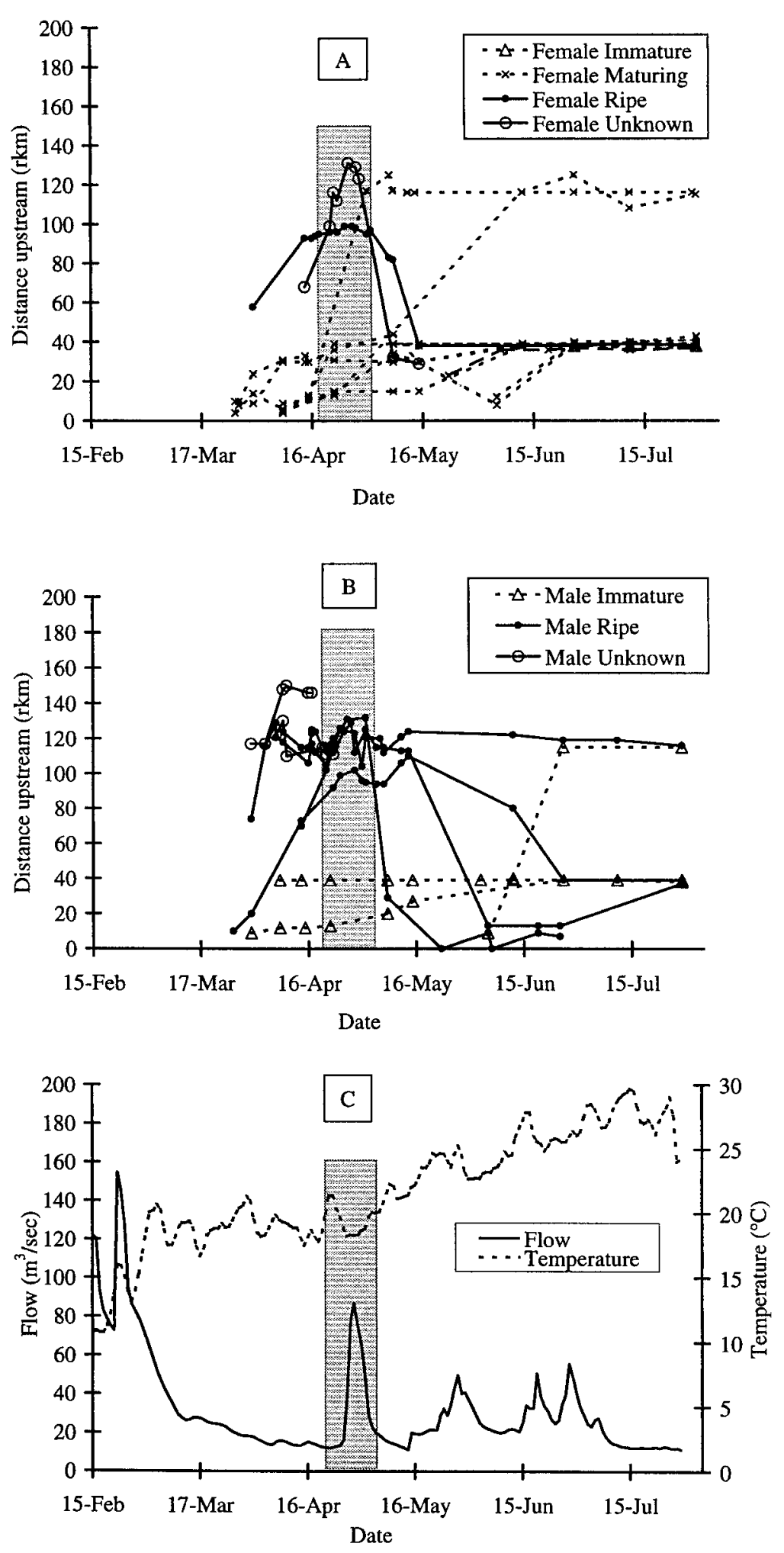

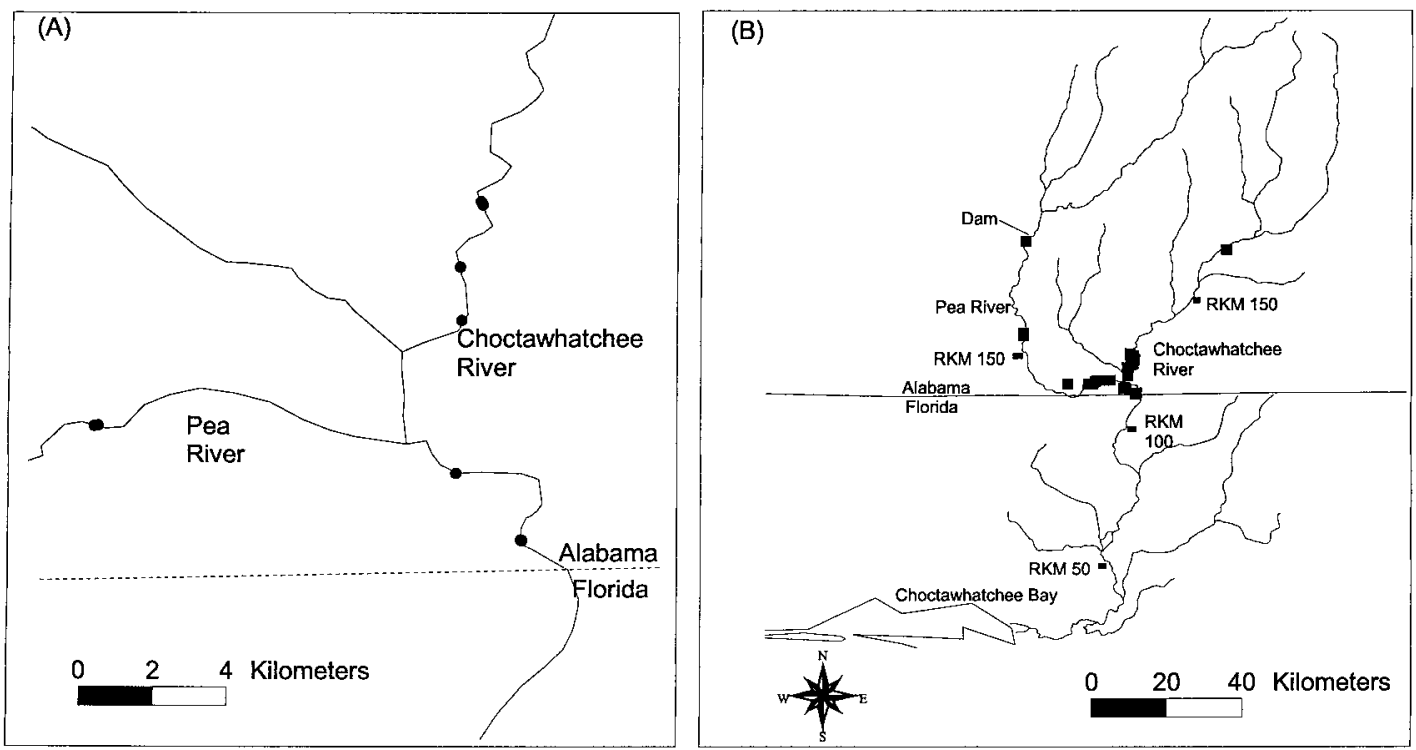

FIGURE 6.-(A) Locations of sites where egg sampling pads were deployed during 1996 and 1997 and fertilized Gulf sturgeon eggs were collected compared with (B) sampling sites where no Gulf sturgeon eggs were collected.

sturgeon. During our 1996 field season, one fish apparently remained in the estuary until early September, after which it was relocated once in the lower Choctawhatchee River. During 1997, three fish were relocated in the bay (ultrasonic tags) through late June when migration upriver began. One Gulf sturgeon moved between the lower river and Choctawhatchee Bay on two occasions in late May and early June 1997. Such movements between fresh and saltwater habitats could not be detected in our previous telemetry studies because only radio transmitters had been used.

Recent work on Atlantic sturgeon migration indicated that both the sex and reproductive status of individual fish affects the migratory behavior of adult Atlantic sturgeon (Van Eenennaam et al. 1996). Prior evidence for differential habitat utilization in Gulf sturgeon based on sex and reproductive status is largely circumstantial. Huff (1975) noted that the low capture rate of spent females in surveys supported the hypothesis that migration routes differed by sex. Similarly, multiyear sampling at the mouth of the Suwannee Riv- er indicated that timing of river entrance of Gulf sturgeon varied according to sex (Carr et al. 1996).

Information about migration and the timing of reproductive cycles is needed to understand the impact of fishing on Gulf sturgeon. Previous studies of both Gulf and Atlantic sturgeon indicate that individuals require prolonged periods for the rebuilding of gonadal material between spawning events. Females required 3-5 years between spawning events, whereas males required 1-5 years (Smith 1985). The finding of maturing males by Huff (1975) provided evidence that spawning was not annual for male Gulf sturgeon. However, we found no maturing males among the 13 males that we examined surgically. Of the three males that were ripe in 1996, one was ripe when recaptured in 1997. The remaining two males returned to the river in 1997 and exhibited movement patterns characteristic of ripe fish (i.e., early river entry and movement to spawning sites). These observations suggest that male Gulf sturgeon may be capable of spawning on an annual basis.

Our evidence regarding spawning periodicity in

$\leftarrow$

FIGURE 5.-Choctawhatchee River relocations (in river kilometers, rkm, upstream from the river mouth), by date, for (A) individual female and (B) male Gulf sturgeon tagged during the 1997 field season. Symbols indicate reproductive status. Panel $(\mathbf{C})$ represents average daily flow rates $\left(\mathrm{m}^{3} / \mathrm{s}\right)$ and daily temperatures $\left({ }^{\circ} \mathrm{C}\right)$ in the Choctawhatchee River by date. The shaded rectangles indicate the interval when fertilized Gulf sturgeon eggs were collected on egg sampling pads. 
females supports the observation that spawning is not annual (Huff 1975). Histological results from the female captured in 1996 and recaptured in 1997 showed that this female was not ripe in consecutive years. This finding is also supported by telemetry evidence for other female Gulf sturgeon. In addition to the one recaptured female, two females that were fitted with transmitters during the 1996 field season returned in 1997. One fish was determined to be ripe in 1996 but during 1997 exhibited movement patterns that appear to be characteristic of a nonripe individual (i.e., delayed river entry and reduced upstream movement). The second returning female was classified as immature in 1996 but exhibited movement patterns in 1997 more characteristic of a ripe female (i.e., early river entry and movement to spawning sites). Our histological results also support a greater than annual interval between spawning events. Three of 9 females in 1996 and 10 of 13 in 1997 were classified as maturing. Results of previous work on Gulf sturgeon (Huff 1975) showed a much lower abundance of females in the maturing category. This discrepancy in findings may be a result of differences in gear selectivity, classification schemes, or the failure of maturing females to return to the rivers each year. Recent work on the closely related Atlantic sturgeon has shown that females with midvitellogenic (i.e., maturing) gonads are absent from collections on the Hudson River (Van Eenennaam and Doroshov 1998). Because Atlantic sturgeon reside in marine waters for 3-5 years between spawning events (Bain 1997), it seems probable that the lack of maturing females is due to their absence on the river sampling sites (Van Eenennaam and Doroshov 1998).

In conclusion, this study provides the first detailed information on the relationship between migratory behavior and both the sex and reproductive status of Gulf sturgeon. In addition, we provide the first descriptions of spawning sites for Gulf sturgeon known outside of the Suwannee River. Our results establish that hard-bottom areas in upper river areas are important for spawning. Although it is probable that Gulf sturgeon spawn in other locations in the upper river, our telemetry results indicate that little or no spawning occurs in the lower portions of the river. Thus, preservation of upper river sites with suitable spawning habitat will become increasingly important as Gulf sturgeon populations rebuild.

\section{Acknowledgments}

The authors are indebted to Michelle LaRue for her assistance with the field component of this study and also for giving comments on earlier versions of this manuscript. This work would not have been possible without the financial support and assistance provided by the Panama City, Florida, U.S. Fish and Wildlife Service office. In particular, we thank Gail Carmody, Bob Jarvis, and Laura Jenkins. We also express our gratitude to the U.S. Geological Survey, Florida-Caribbean Science Center, Gainesville, Florida, for their technical assistance and loan of egg samplers. In particular we thank Ken Sulak and Les Parker. For help with both histological and egg staging techniques, we thank Frank Chapman and the University of Florida. We also recognize Mark Collins, Dave Eggleston, John Godwin, Mary Moser, Ted Smith, Ken Sulak, and two anonymous reviewers for their comments and reviews of this manuscript.

\section{References}

Altinok, I. 1997. Hydromineral regulation capabilities of juvenile Gulf of Mexico sturgeon (Acipenser oxyrinchus desotoi). Master's thesis. University of Florida, Gainesville.

Artyukhin, Y. N., A. D. Sukhoparova, and L. G. Fimukhina. 1979. The gonads of the sturgeon, Acipenser güldenstädti, in the zone below the dam of the volgograd water engineering station. Journal of Ichthyology 18:912-923.

Bain, M. B. 1997. Atlantic and shortnose sturgeons of the Hudson River: common and divergent life history attributes. Environmental Biology of Fishes 48: 347-358.

Bass, G. D., D. M. Yeager, and V. G. Hitt. 1980. Ecology of the Choctawhatchee River system, Florida. Florida Game and Freshwater Fish Commission, Northwest Streams Research Project, Tallahassee.

Bemis, W. E., E. K. Findeis, and L. Grande. 1997. An overview of Acipenseriformes. Environmental Biology of Fishes 48:25-71.

Bemis, W. E., and B. Kynard. 1997. Sturgeon rivers: an introduction to acipenseriform biogeography and life history. Environmental Biology of Fishes 48: $167-183$.

Buckley, J., and B. Kynard. 1985. Yearly movements of shortnose sturgeons in the Connecticut River. Transactions of the American Fisheries Society 114: 813-820.

Burgess, R. F. 1963. Florida sturgeon spree. Outdoor Life (March):44.

Carr, S. H., F. Tatman, and F. A. Chapman. 1996. Observations on the natural history of the Gulf of Mexico sturgeon (Acipenser oxyrinchus desotoi, Vladykov 1955). Ecology of Freshwater Fish 5:169174.

Chapman, F. A., and S. H. Carr. 1995. Implications of early life stages in the natural history of the Gulf of Mexico sturgeon, Acipenser oxyrinchus desotoi. Environmental Biology of Fishes 43:407-413.

Chapman, F. A., J. P. Van Eenennaam, and S. I. Doro- 
shov. 1996. The reproductive condition of white sturgeon (Acipenser transmontanus), in San Francisco Bay, California. Fishery Bulletin 94:628-634.

Clugston, J. P., A. M. Foster, and S. H. Carr. 1995. Gulf sturgeon Acipenser oxyrinchus desotoi in the Suwannee River, Florida, USA. Pages 215-224 in A. D. Gershanovich and T. I. J. Smith, editors. Proceedings second international symposium on the sturgeon (September 1993, Moscow). VNIRO Publishing, Moscow.

Conte, F. S., S. I. Doroshov, P. B. Lutes, and E. M. Strange. 1988. Hatchery manual for the white sturgeon Acipenser transmontanus Richardson, with application to other North American Acipenseridae. University of California, Cooperative Extension, Division of Agriculture and Natural Resources, Publication 3322, Davis.

Dovel, W. L., and T. J. Berggren. 1983. Atlantic sturgeon of the Hudson estuary, New York. New York Fish and Game Journal 30:140-172.

Foster, A. M. 1993. Movement of Gulf sturgeon, Acipenser oxyrinchus desotoi, in the Suwannee River, Florida. Master's thesis. University of Florida, Gainesville.

Foster, A. M., and J. P. Clugston. 1997. Seasonal migration of Gulf sturgeon in the Suwannee River, Florida. Transactions of the American Fisheries Society $126: 302-308$.

Hall, J. W., T. J. Smith, and S. D. Lamprecht. 1991. Movements and habitats of shortnose sturgeon Acipenser brevirostrum in the Savannah River. Copeia 1991:695-702.

Harms, C. A., and R. S. Bakal. 1994. Techniques in fish anesthesia. American Association of Zoo Veterinarians Annual Proceedings 1994:202-210.

Holcik, J., editor. 1989. The freshwater fishes of Europe, volume 1, part II: general introduction to fishes, Acipenseriformes. AULA-Verlag, Wiesbaden, Germany.

Huff, J. A. 1975. Life history of Gulf of Mexico sturgeon, Acipenser oxyrinchus desotoi, in Suwannee River, Florida. Florida Department of Natural Resources, Marine Research Laboratory, 16, St. Petersburg.

Kempinger, J. J. 1988. Spawning and early life history of lake sturgeon in the Lake Winnebago system, Wisconsin. Pages 110-122 in R. D. Hoyt, editor. 11 th annual larval fish conference. American Fisheries Society, Symposium 5, Bethesda, Maryland.

Kenward, R. E. 1992. Quantity versus quality: programmed collection and analysis of radio-tracking data. Pages 231-246 in I. G. Preiede and S. M. Swift, editors. Wildlife telemetry: remote monitoring and tracking of animals. Ellis Horword, New York.

Kieffer, M. C., and B. Kynard. 1993. Annual movements of shortnose and Atlantic sturgeons in the Merrimack River, Massachusetts. Transactions of the American Fisheries Society 122:1088-1103.

Kynard, B. 1997. Life history, latitudinal patterns, and status of the shortnose sturgeon, Acipenser brevi- rostrum. Environmental Biology of Fishes 48:319334.

LaHaye, M., A. Branchaud, M. Gendron, R. Verdon, and R. Fortin. 1992. Reproduction, early life history, and characteristics of the spawning grounds of the lake sturgeon (Acipenser fulvescens) in Des Prairies and L'Assomption rivers, near Montréal, Quebec. Canadian Journal of Fisheries and Aquatic Sciences 70:1681-1689.

Livingston, R. J., J. H. Epler, F. Jordan, W. R. Karsteter, C. C. Koenig, A. K. Prasad, and G. L. Ray. 1991. Ecology of the Choctawhatchee River system. Pages 247-274 in R. J. Livingston, editor. Ecological studies analysis and synthesis, volume 83: the rivers of Florida. Springer-Verlag, New York.

Marchant, R. S., and M. K. Sutters. 1996. Artificial substrates collect gulf sturgeon eggs. North American Journal of Fisheries Management 16:445-447.

McCabe, G. T., Jr. 1990. Use of an artificial substrate to collect white sturgeon eggs. California Fish and Game 76:248-250.

McCabe, G. T., Jr., and C. A. Tracy. 1994. Spawning and early life history of white sturgeon (Acipenser transmontanus) in the lower Columbia River. Fishery Bulletin 92:760-772.

O'Herron, J. C., II., K. W. Able, and R. W. Hastings. 1993. Movements of shortnose sturgeon (Acipenser brevirostrum) in the Delaware River. Estuaries 16: 235-240.

Parauka, F. M., W. J. Troxel, F. A. Chapman, and L. G. McBay. 1991. Hormone-induced ovulation and artificial spawning Gulf of Mexico sturgeon Acipenser oxyrinchus desotoi. Progressive Fish-Culturist 53: 113-117.

Parsley, M. J., L. G. Beckman, and G. T. McCabe, Jr. 1993. Spawning and rearing habitat use by white sturgeons in the Columbia River downstream from McNary Dam. Transactions of the American Fishery Society 122:217-227.

Schaffter, R. G. 1997. White sturgeon spawning migrations and location of spawning habitat in the Sacramento River, California. California Fish and Game 83:1-20.

Smith, T. I. J. 1985. The fishery, biology, and management of Atlantic sturgeon, (Acipenser oxyrinchus), in North America. Environmental Biology of Fishes 14:61-72.

Smith, T. I. J., and J. P. Clugston. 1997. Status and management of Atlantic sturgeon (Acipenser oxyrinchus) in North America. Environmental Biology of Fishes 48:335-346.

Stabile, J., J. R. Waldman, F. Parauka, and I. Wirgin. 1996. Stock structure and homing fidelity in Gulf of Mexico sturgeon (Acipenser oxyrinchus desotoi) based on restriction fragment length polymorphism and sequence analysis of mitochondrial DNA. Genetics 144:767-775.

Sulak, K. J., and J. P. Clugston. 1998. Early life history stages of Gulf sturgeon in the Suwannee River, Florida. Transactions of the American Fisheries Society 127:758-771.

U.S. Commission of Fish and Fisheries. 1902. Report 
of the Commissioner (part XXVII) for the year ending June 30, 1901. U.S. Government Printing Office, Washington, D.C.

U.S. Fish and Wildlife Service and the Gulf States Marine Fisheries Commission. 1995. Gulf sturgeon recovery plan. U.S. Fish and Wildlife Service, Atlanta.

Van Eenennaam, J. P., and S. I. Doroshov. 1998. Effects of age and body size on gonadal development of Atlantic sturgeon. Journal of Fish Biology 53:624637.

Van Eenennaam, J. P., S. I. Doroshov, G. P. Moberg, J. G. Watson, D. S. Moore, and J. Linares. 1996. Reproductive conditions of the Atlantic sturgeon (Acipenser oxyrinchus) in the Hudson River. Estuaries 19:769-777.
Wei, Q., F. Ke, J. Zhang, P. Zhuang, J. Luo, R. Zhou, and W. Yang. 1997. Biology, fisheries, and conservation of sturgeons and paddlefish in China. Environmental Biology of Fishes 48:241-255.

Wooley, C. M., P. A. Moon, and J. Crateau. 1982. A larval Gulf of Mexico sturgeon Acipenser oxyrhynchus desotoi in the Apalachicola River, Florida. Northeast Gulf Science 5:57-58.

Zhong-Ling, D., and X. Y. Z. Yan. 1991. Analysis on Acipenser sinensis spawning ground and spawning scales below Gezhouba hydro-electric dam by the means of examining the digestive contents of benthic fishes. Pages 243-250 in P. Williot, editor. Acipenser. CEMAGREF Publishers, Bordeaux, France. 